\title{
Metabolic pathway of oligosaccharides in sorghum honeydew caused by Claviceps africana
}

\author{
Rota metabólica de oligossacarídeos em exsudato da “doença açucarada” do sorgo \\ causado por Claviceps africana
}

\author{
Amauri Bogo ${ }^{\mathrm{I}}$ Peter Mantle
}

\begin{abstract}
The occurrence of the alditol oligosaccharides in the Claviceps afriana honeydew is partly as a rational expression of the pathogen's selective nutritive metabolism of the sucrose supplied by the host plant. The experiments were carried out in laboratory and when ${ }^{14} \mathrm{C}$ - $D$-sucrose, ${ }^{14} \mathrm{C}$ - $D$-fructose or ${ }^{14} \mathrm{C}-\mathrm{D}$ mannitol radiolabelled saccharides were incorporated into: a) sorghum plant infected by $C$. africana, b) whole and macereted micelia tissue and c) cell-free honeydew of C. africana, it was observed that the glucose moiety of sucrose was not involved in oligosaccharides formation. Glucose was used by the pathogen as nutritional source. Part of the unused fructose moiety was reduced to mannitol by the pathogen's enzymes which was also excreted into honeydew where reductase activity accepted ${ }^{14} \mathrm{C}$ mannitol. The mannitol was linked with fructose in a 2-position synthesizing the disaccharide 1- $\beta-D$-fructofuranosyl-Dmannitol and then the process was repeated by the mannitol moiety of the disaccharide to yield the trisaccharide 1,6-di- $\beta$ D-fructofuranosyl-D-mannitol, which became dominant. The direct formation of alditol saccharides from monosaccharides in this way seems to be unique to C. africana, contrasting with the fructosyl transfer from sucrose to sucrose which is usual in others ergot parasites.
\end{abstract}

Key words: biosynthesis, metabolic pathway, oligosaccharides, ergot.

\section{RESUMO}

A ocorrência de oligossacarídeos contendo alditol em exsudações da doença açucarada produzidos por Claviceps africana é em parte uma expressão racional do metabolismo seletivo de nutrição do patógeno na tansformação da sacarose fornecida pela planta. Quando açúcares radioativos marcados com ${ }^{14} \mathrm{C}$ (D-sucrose, D-fructose e D-mannitol) foram incorporados em: a) planta do sorgo infectada por C. africana, b) tecido micelial inteiro e macerado isolado de C. africana $e$ c) exsudato livre de células de C. africana, foi observado que a glicose da sacarose não estava envolvida na formação de oligossacarídeos, sendo usada pelo patógeno como fonte nutritiva. Parte da frutose não utilizada da sacarose foi reduzida a mannitol por enzimas do patógeno. As enzimas envolvidas também atuaram no exsudato da "doença açucarada”, ativando a ação da redutase pela incorporação do ${ }^{14} \mathrm{C}$ manitol. $\mathrm{O}$ manitol foi ligado na posição 2 da fructose, formando o dissacarídeo 1 - $\beta$ - $D$-fructofuranosyl-D-mannitol $e$, posteriormente, adicionada mais uma fructose ao mannitol do dissacarídeo, formando o trisacarídeo 1,6-di- $\beta$-Dfructofuranosyl-D-manitol, que se tornou predominate. A formação direta de oligossacarídeos contendo alditol a partir de monossacarídeos parece ser exclusiva em C. africana, contrastando com a ação enzimática da frutose transferase a partir de sucrose para sucrose, a qual é muito comum em outros patógenos tipo "ergot".

Palavras-chave: biossíntese, rota metabólica, oligosacarídeos, ergot.

\section{INTRODUCTION}

The honeydew sugars are important from the standpoint of pathogen epidemiology and carbon assimilation (DICKERSON, 1972). The sugar composition of the honeydew exudate from ergot fungi parasiting grasses and cereals hosts has, until recently, been largely of academic interest, concerning only the resumed bland mixture of oligossacharides arising from the pathogen's preferred use of the glucose component of the host's sucrose (MOWER et al., 1973). In most species of ergot, several sugars are formed in the honeydew, and the resulting higher osmotic concentration in the floral cavity serves to draw in host

'Departamento de Fitotecnia, Centro de Ciências Agroveterinárias (CAV), Universidade do Estado de Santa Catarina (UDESC). Av.
Luis de Camões, 2090, 88520-000, Lages, SC, Brasil. E-mail: a2ab@cav.udesc.br. Autor para correspondência.

IImperial College of Science, Technology and Medicine, London, SW7-2AY, UK. 
fluids. Epidemiologically, the honeydew sugars have a function in the preservation of the conidia during dry periods and support the secondary sporulation for dispersal of conidia to other flowers. Recent spread of the pathogen around the world has focused attention on macrospores germination which is the most important factor in creating epidemics of ergot disease. The carbohydrate D-mannitol is a major soluble component in most higher fungi, in over fifty families of the angiosperms, and in many genera of the red and brown algae, liquens and liverworts (LEWIS \& SMITH, 1967). Experiments using ${ }^{14} \mathrm{C}$ with species of fungi known to contain large amounts of mannitol have generally shown that the hexitol is a primary product of heterotrophic assimilation (LEWIS, 1971).

Sucrose accounts for over $90 \%$ of the total soluble carbohydrate in most samples of the first drop of freshly exuded honeydew uncontaminated with fungal spores. Oligosaccharides are only found when the honeydew has been in contact with parasitic fungal tissue, a condition which may be correlated with the presence of spores in the exudate (MOWER \& HANCOCK, 1975).

Incorporation of specifically radio labelled sugars into storage compounds have provided much information about carbohydrate metabolism of fungi (DICKERSON, 1972). However, no consideration has previously been given to the possibility that the intermediate metabolism of certain acyclic polyols could lead to significant changes in the molecular distribution of radioactivity in related sugars. Thus, it appears that honeydew synthesis depends on the activities of fungal enzymes, and evidence is reported here supporting the idea of a mechanism of honeydew formation. Whereby sucrose is drown from the host by conversion to new sugars in the diseased floral cavity.

\section{MATERIAL AND METHODS}

Male-sterile sorghum (Sorghum bicolor L.)(IS 2219 A) was grown in a horticultural tunnel at the Chelsea Physic Garden, London, and flowered in August and September. Florets were inoculated with C. africana at floret gaping by spraying diluted natural honeydew with spore concentration around $1.10^{4}$ conidia $\mathrm{mL}^{-1}$. New parasitic tissues exuded honeydew 1-2 weeks after floret inoculation. From these plants, fresh mycelial tissue of Sphacelia sorghi (anamorphic form of $\boldsymbol{C}$. africana) from the infected florets and honeydew were collected in a test tube and submitted to three different treatments: a. $1 \mathrm{~mL}$ of cellfree honeydew; b. $1 \mathrm{~mL}$ of water containing fresh whole
S. sorghi tissue (approximately 3g) colleted from the infected florets and, c. homogenate of $\boldsymbol{S}$. sorghi tissue (approximately 3g) colleted from infected florets in $1 \mathrm{~mL}$ of water macerated with a mortar and pestle. To each treatment $1 \mu \mathrm{Ci}$ of ${ }^{14} \mathrm{C}$-sucrose, ${ }^{14} \mathrm{C}$ fructose or ${ }^{14} \mathrm{C}$ mannitol was added. The tubes were placed in a shaker and $50 \mu \mathrm{L}$ samples were collected at intervals of $0 ; 0.05$; 1; 3 and 4 hours and evaluated. The experiments were made with 4 replicates in each treatment. Experiments with radiolabeled substrates were carried out also with C. sorguicola and $\boldsymbol{C}$. purpurea. In other experiment, two potted sorghum plants with honeydew symptoms were collected from the tunnel and $100 \mu \mathrm{L}$ of water containing $4 \mu \mathrm{Ci}$ of ${ }^{14} \mathrm{C}$-sucrose were injected with micro syringe in the last internode. The honeydew produced at intervals of $20 \mathrm{~h}$ and $40 \mathrm{~h}$ in the laboratory was collected and evaluated.

Products derived from the experiments by native enzyme action on ${ }^{14} \mathrm{C}$-labelled substrates were determined by paper chromatography and by a combination of FAB-MS (Fast atom bombardment mass spectrometry) and GC-MS (gas chromatography - mass spectrometry). Oligosaccharides isolation: Descending paper chromatography [Whatman 3MM No. 1 paper; solvent, propan-1-ol:ethyl acetate:water (7:1:2)] for 48-55h resolved standards (D-fructose, Dglucose, sucrose and raffinose) and analytically and/ or preparatively separated sugars in $100 \mu \mathrm{L}$ of honeydew. To localize the sugars, lateral strips of the chromatograms were stained in aniline hydrogen phthalate reagent (BOGO, 2001) and heated at $120^{\circ}$ for $20 \mathrm{~min}$. The oligosaccharides separated in the chromatograms were eluted through a $2.5-\mathrm{x} 40-\mathrm{cm}$ column of Bio-Gel P-2 (Bio-Rad) equilibrated in degassed water at $0.4 \mathrm{~mL} \mathrm{~min}^{-1}$. The eluate was monitored with a Waters RI-detector R-403 and the fractions $(5 \mathrm{~mL})$ were collected with an LKB fraction collector, using an Hitachi 561 Recorder. The fractions collected were freeze-dried prior to saccharide analysis and bioassay. The dried chromatograms papers were exposed to Kodirex No-screen X-ray film for 3 days. The autoradiographs obtained were used to determine the radioactive areas, which were removed, cut in small pieces and centrifuged in eppendorff's vessels. The volume was dried down to at least $1 \mathrm{~mL}$ and added in liquid scintillate. The radioactivity in the samples was determined by a Packard counter (model 3003).

Oligosaccharide composition was determined by a combination of FAB-MS and GC-MS analysis. For FAB-MS analysis, oligosaccharides were reduced on a DuPont Model 21-491 instrument with DMSO plus $\mathrm{NaOH}$, reduced with borohydride and permethylated with methyl iodide as described by DELL 
et al. (1994). For GC-MS analysis, the permethylated saccharides, after the standard procedure of hydrolysis in $1 \mathrm{M}$ trifluroacetic acid (TFA) at $25^{\circ} \mathrm{C}$ for $30 \mathrm{~min}$, followed by reduction with sodium borodeuteride and acetylation with acetic anhydride, as described by CARPITA \& SHEA(1989). GC-MS was carried out on a Finnigan/MAT 9610 gas chromatograph equipped with a 30-m x 0.2-mm DB-5 capillary column in a temperature gradient $90-190^{\circ}\left(20^{\circ} \mathrm{min}^{-1}\right), 190-210^{\circ}\left(1^{\circ} \mathrm{min}^{-1}\right), 210$ $300^{\circ}\left(25^{\circ} \mathrm{min}^{-1}\right)$. The system was combined by two phases. A phase employed a Fisons 8000 quadrupole mass spectrometer system in electron impact mode, and B a VG autospek Q system in chemical ionisation with negative ion mode to show molecular ions of derivatised monosaccharides.

The ${ }^{14} \mathrm{C}$-labelled honeydew from the potted plants was analysed by quantification of the percentage of free D-glucose and total D-fructose after hydrolysis in $1 \mathrm{M}$ of TFA. Total D-fructose represented a combination of free D-fructose, the D-fructose in sucrose and D-fructose in oligosaccharides. D-Glucose was determinated using the glucose oxidase assay (FLEMING \& PEGLER, 1963) and D-fructose was quantified as a keto-sugar using Seliwanoff reaction (BACON \& BELL, 1948). The glucose and fructose quantification was made by reading the absorbance in four different dilutions with three replicates each and related to a standard curve of D-glucose and D-fructose. The optical density of each solution was measured against the blank (reagents incubated with water) at $455 \mathrm{~nm}$ wavelength using a spectrophotometer (MSE Spectroplus). Standard glucose and fructose solutions
(10-90 $\mu \mathrm{g} \mathrm{mL}^{-1}$ ), prepared in saturated benzoic acid and diluted with water, were treated similarly and gave linear calibration curve and analysis of variance (ANOVA) was used for statistical analysis. Concentration of each sample was expressed as ( $\mathrm{g} \mathrm{mL}^{-1}$ using the D-fructose standard curve.

Concerning the data illustrated in figures 1 to 3, the bar at the time ' 0 '(zero) consistently indicates only that $100 \%$ of the pulse labelling ${ }^{14} \mathrm{C}$ given was in the form of the particular saccharide. All other data within each subsequent time point represent the proportions of the various sugars, which make up the total ${ }^{14} \mathrm{C}$ recovered (100\%).

\section{RESULTS AND DISCUSSION}

FAB-MS spectra of $\boldsymbol{C}$. africana honeydew collected from the potted plant before inoculation with radiolabeled substrates showed the presence of two major oligosaccharides, one with ion $\mathrm{m} / \mathrm{z} 493$ (disaccharide) and the other with $\mathrm{m} / \mathrm{z} 697$ (trisaccharide), confirming the data published in BOGO et al. (2006).

The ${ }^{14} \mathrm{C}$-sucrose, when injected directly in the plant, suffered almost total hydrolysis in the first 20 hours (Figure 1), liberating fructose and glucose as well as incorporating approximately $50 \%$ of radiolabell in 1- $\beta$-D-fructofuranosyl-D-mannitol and 1,6-di- $\beta$-Dfructofuranosyl-D-mannitol. After 40 hours the incorporation of ${ }^{14} \mathrm{C}$-sucrose in 1 - $\beta$-D-fructofuranosylD-mannitol and 1, 6-di- $\beta$-D-fructofuranosyl-D-mannitol was approximately $60 \%$, with approximately $10 \%$ in 1$\beta$-D-fructofuranosyl-D-mannitol and 50\% in 1,6-di- $\beta$ -

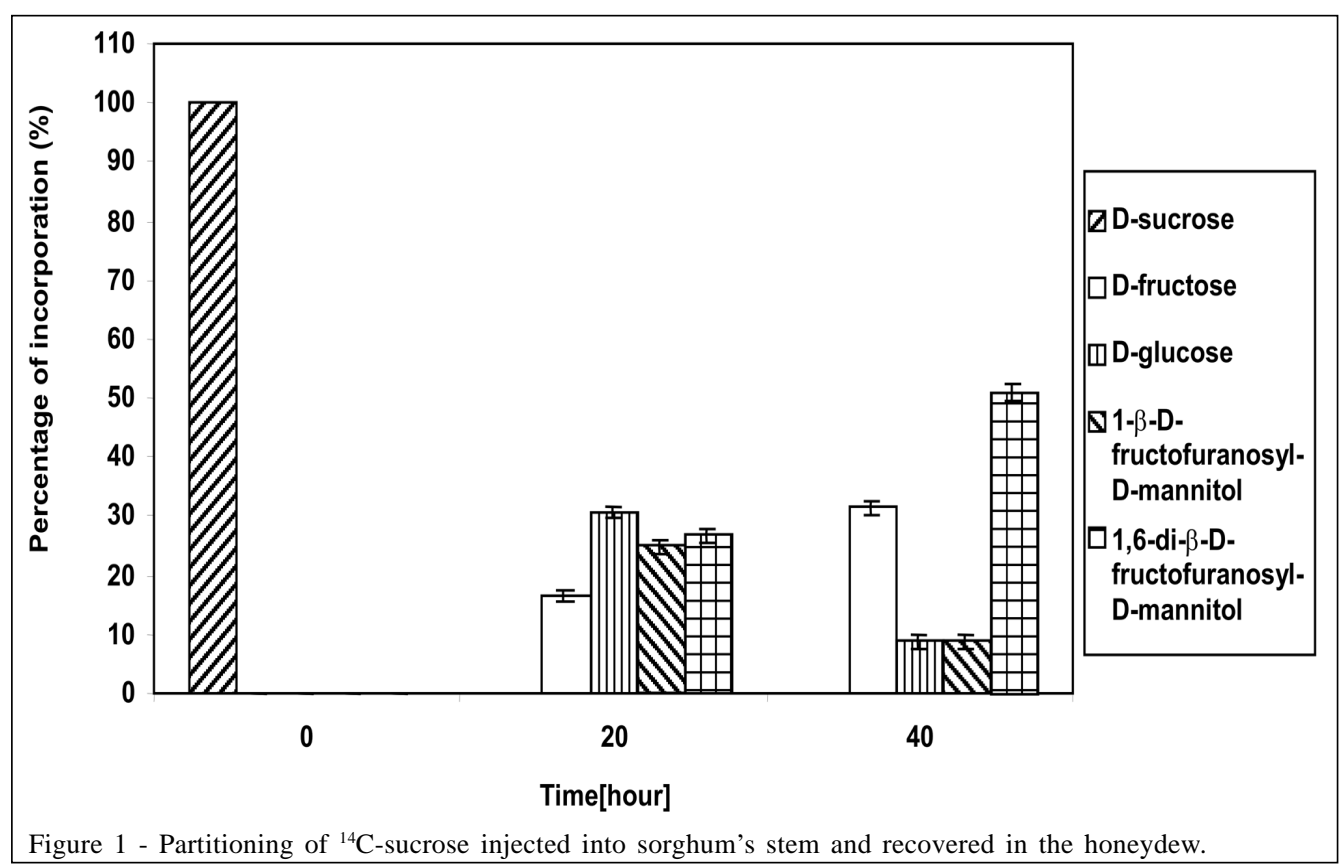

Ciência Rural, v.38, n.4, jul, 2008. 


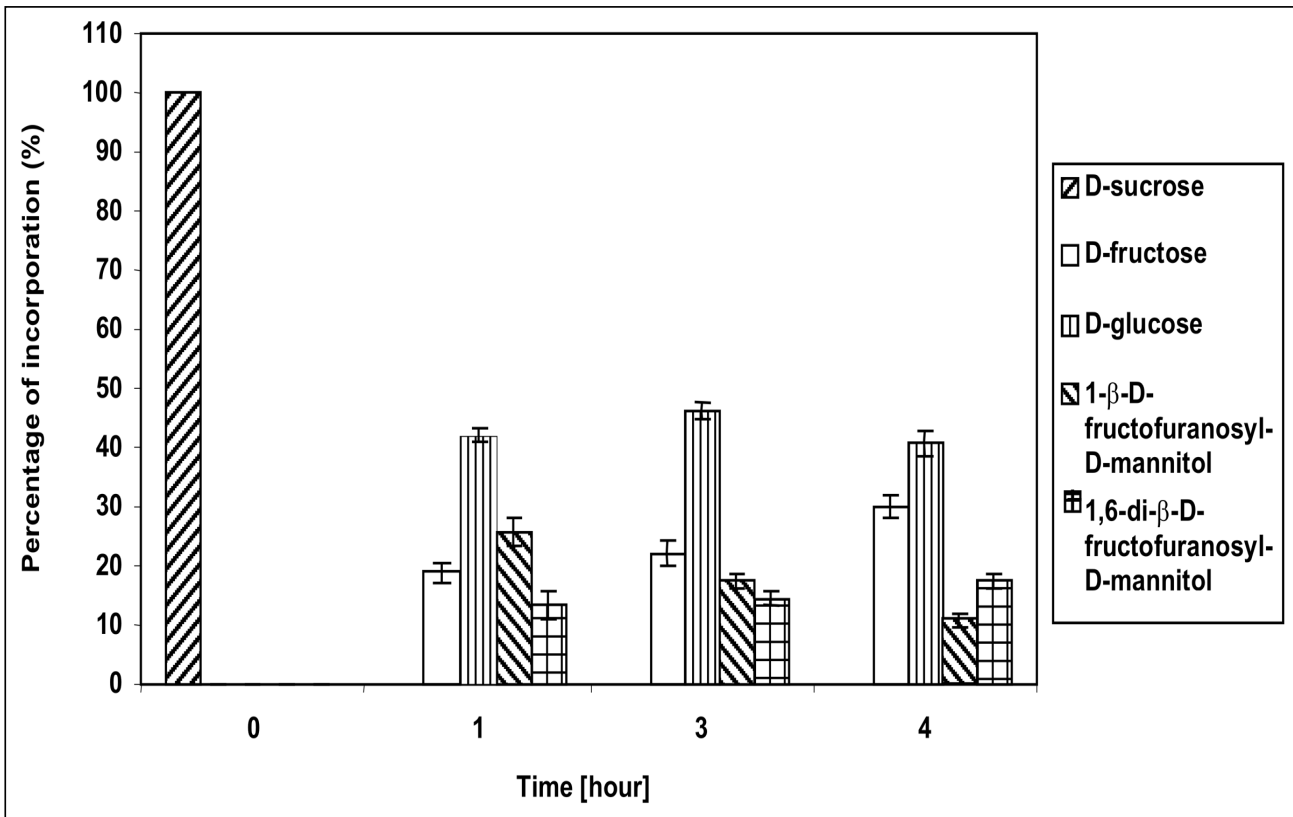

Figure 2 - Partitioning of ${ }^{14} \mathrm{C}$-sucrose added to $\boldsymbol{C}$. africana's cell free-honeydew.

D-fructofuranosyl-D-mannitol (Figure 1). The amount of glucose after 40 hours was $1 / 3$ of glucose available in the first 20 hours, suggesting that it could be due to fungus's assimilation for mycelium growth. During the experiment there was an increase in the amount of fructose until the total hydrolysis of sucrose. The cell free honeydew treated with ${ }^{14} \mathrm{C}$-sucrose (Figure 2) or ${ }^{14} \mathrm{C}$-mannitol showed significant incorporation of radiolabell from both into 1- $\beta$-D-fructofuranosyl-D- mannitol and 1,6-di- $\beta$-D-fructofuranosyl-D-mannitol in the first hours. After a period of 4 hours approximately $80 \%$ of ${ }^{14} \mathrm{C}$-mannitol was incorporated into $1-\beta$-Dfructofuranosyl-D-mannitol and 1,6-di- $\beta$-Dfructofuranosyl-D-mannitol, higher than for ${ }^{14} \mathrm{C}$ sucrose, that did not exceed approximately $30 \%$ (Figure 2 ), due to the predicted non-involved glucose moiety of sucrose. When ${ }^{14} \mathrm{C}$-fructose was added to the cellfree honeydew, even after 4 hours, no incorporation of

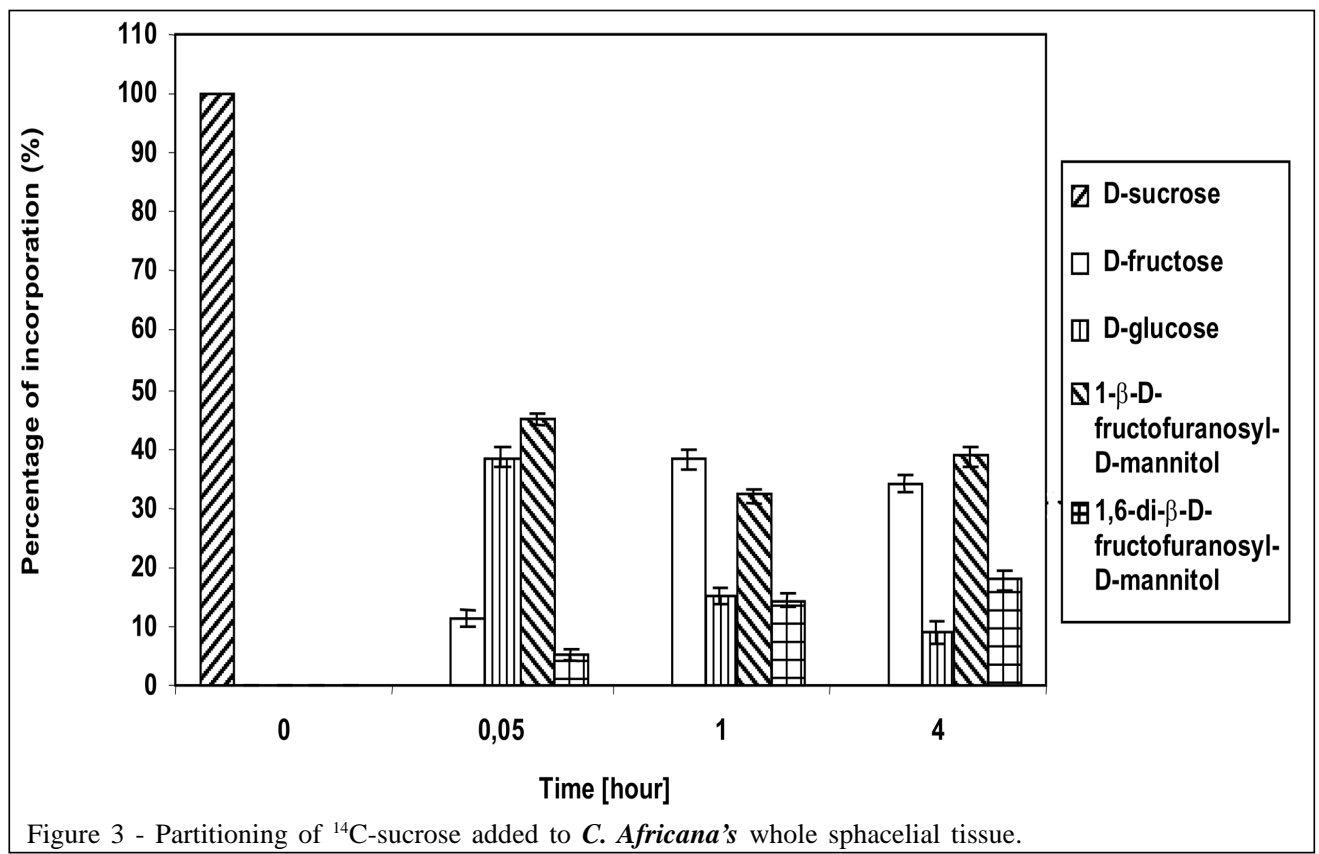

Ciência Rural, v.38, n.4, jul, 2008. 
radiolabell was observed. The fresh whole Sphacelia's tissue incubated with ${ }^{14} \mathrm{C}$-sucrose showed approximately $60 \%$ of incorporation of radiolabell in 1$\beta$-D-fructofuranosyl-D-mannitol and 1,6-di- $\beta$-Dfructofuranosyl-D-mannitol (Figure 3) when compared to ${ }^{14} \mathrm{C}$-sucrose in cell-free honeydew in which incorporation was approximately $30 \%$ (Figure 2). The fresh whole Sphacelia's tissue when incubated with ${ }^{14} \mathrm{C}$-mannitol and ${ }^{14} \mathrm{C}$-fructose showed, after 4 hours, a similar proportion between both oligosaccharides, but the incorporation of radiolabell into both oligosaccharides was approximately $45 \%$ with ${ }^{14} \mathrm{C}$ mannitol and approximately $30 \%$ with ${ }^{14} \mathrm{C}$-fructose. When Sphacelia's tissue was macerated, the incorporation of ${ }^{14} \mathrm{C}$-sucrose, ${ }^{14} \mathrm{C}$-mannitol and ${ }^{14} \mathrm{C}$ fructose into 1- $\beta$-D-fructofuranosyl-D-mannitol and 1,6-di- $\beta$-D-fructofuranosyl-D-mannitol was in general slightly more efficient compared to the whole Sphacelia's tissue. Particularly, the incorporation of ${ }^{14} \mathrm{C}$-mannitol into the oligosaccharides with macerated Sphacelia's tissue was approximately 1.5 times more efficient than compared with non macerated tissue (data not shown).

When ${ }^{14} \mathrm{C}$-sucrose, ${ }^{14} \mathrm{C}$-mannitol or ${ }^{14} \mathrm{C}$ fructose were added to cell-free-honeydew of $\boldsymbol{C}$. purpurea and $\boldsymbol{C}$. sorghicola, ${ }^{14} \mathrm{C}$-sucrose was incorporated into a trisaccharides group, but these do not contain an alditol component (BOGO, 2001). ${ }^{14} \mathrm{C}$ mannitol and ${ }^{14} \mathrm{C}$-fructose were clearly not involved because no radiolabell incorporation was observed. These findings are consistent with the well-established principle that all these oligosaccharides containing one molecule of glucose are derived only from sucrose molecules (DICKERSON, 1972; DICKERSON et al., 1978; POLLARD \& DICKERSON, 1984).

The distribution of various sugars in $\boldsymbol{C}$. africana honeydew, collected from the plants before treatment with ${ }^{14} \mathrm{C}$-sucrose, showed low percentage of free fructose (13.6\%) (Table 1). The majority of the total fructose is distributed in 1- $\beta$-D-fructofuranosyl-Dmannitol (25.9\%) and 1,6-di- $\beta$-D-fructofuranosyl-Dmannitol (60.5\%).

During the processes of sucrose catabolism and transformation by the enzymes of the sphacelial mass of C. africana, glucose moiety of sucrose is detached permitting it to be assimilated by the growing fungus. The fructose moiety of sucrose, which initially is not used as nutrition source, is reduced to mannitol by fructose dehydrogenase and subsequently creating a serious of oligosaccharides containing alditol. The C. africana oligosaccharides metabolic pathway in the honeydew is important to allow the formulation of a putative biosynthetic route to create alditol-containing
Table 1 - Detailed composition of C. africana early-stage honeydew sample from male-sterile grain sorghum (2219A) collected from Chelsea Physic Garden green house immediately before injection with ${ }^{14} \mathrm{C}$ sucrose. Individual sugars analysed after descending paper chromatography and expressed as $\mu \mathrm{g} \mathrm{ml} \mathrm{m}^{-1} \pm$ standard deviation $(\mathrm{n}=4)$.

\begin{tabular}{ll}
\hline Individual sugars & Concentration $\left(\mu \mathrm{g} \mathrm{ml}^{-1}\right)$ \\
\hline free fructose & $0.35 \pm 0.013(13.6 \%)$ \\
free glucose* & $0.131 \pm 0.02$ \\
fructosyl - mannitol• & $0.666 \pm 0.01(25.9 \%)$ \\
difructosyl - mannitol• & $1.578 \pm 0.04(60.5 \%)$ \\
total fructose & $2.714 \pm 0.018$ \\
\hline
\end{tabular}

• obtained by Seliwanoff assay; *obtained by glucose oxidase assay.

oligosaccharides. The alditol mannitol arises by reduction of fructose in the sphacelial tissue and the formation of oligosaccharides is achieved as cellassociated metabolism. C. africana reduces fructose to mannitol and the enzymes present in the honeydew link one molecule of mannitol to the fructose moiety of sucrose. By GC-MS linkage analysis, mannitol is linked in a 2-position of fructose creating the disaccharide 1$\beta$-D-fructofuranosyl-D-mannitol. Similar linkage occurs with glucose moiety in the sucrose substrate which occurs without the fructose moiety ever being free. When the biotransformation occurs in the cellassociated, glucose is liberated for direct utilisation by the pathogen's metabolism but if the biotransformation occurs within exuded honeydew, free glucose is utilised for spores metabolism, including secondary sporulation. The mannitol in the disaccharide 1- $\beta$-Dfructofuranosyl-D-mannitol is randomly linked 1-2 or 6-2 to fructose and addition of an extra fructose, also linked by its 2-position to the remaining 1- or 6- positions of mannitol in the disaccharide, gives the trisaccharide 1,6 -di- $\beta$-D-fructofuranosyl-D-mannitol. As in the formation of the disaccharide, mannitol becomes linked to an eventual 2-position of a fructose in another sucrose molecule, with concomitant release of glucose, but in this case the mannitol is already linked to a fructose moiety and creates a trisaccharide.

C. sorghi and C. sorghicola honeydew saccharides are mainly fructose and glucose (BOGO, 2001), and the principal mode of utilisation of the host's sucrose is via an invertase hydrolysing of sucrose to monosaccharides fructose and glucose. Normally, the developing sphacelium of $\boldsymbol{C}$. africana utilises virtually all of the sucrose supplied by the sorghum floret. This is why the concentration of saccharides in the honeydew is generally so low. The glucose moiety of 
sucrose is metabolised by the pathogen as a carbon and energy source, and the fructose moiety, partially reduced to mannitol, is incorporated into oligosaccharides. The biosynthetic mechanism of linking mannitol to fructose molecules and the enzyme activity explain the increase in the concentration of bioactive oligosaccharides in honeydew.

\section{REFERENCES}

BACON, J.S.D; BELL, D.J. Glucose and fructose in the blood of the fetal sheep. Biochemical Journal, London, v.42, p.397-399, 1948.

BOGO, A. Biochemical physiopathology of some ergot fungi and other honeydew-producing plant parasites. 2001. 141f. (PhD Thesis in Plant Pathology) - University of London, London/UK.

BOGO, A. et al. The structures of the honeydew oligosaccharides synthesized by Claviceps africana. Summa Phytopathologica, Botucatu, v.32, n.1, p.16-20, 2006.

CARPITA, N.C; SHEA, E.M. CRC-Analysis of Carbohydrates by GLC and MS. London CRC. Biermann \& McGinnis, 1989. 291p.

DELL, A. et al. Methods in enzymology. London: Lennarz. J. Wiley \& G. W. Hart., 1994. 230p.
DICKERSON, A.G. A $\beta$-D-Fructofuranosidase from Claviceps purpurea. Biochemical Journal, London, v.129, p.263272, 1972.

DICKERSON, A. et al. A role of $\beta$-glucanases in the parasitism of cereals by Claviceps purpurea. Physiological Plant Pathology, London, v. 12, p. 55-62, 1978.

FLEMING, I.D.; PEGLER, H.F. The separation of sugars by enzymatic reaction. Analytical, London, v.88, p.967, 1963.

LEWIS, D.H.; SMITH, D.C. Sugars alcohol's (polyols) in fungi and green plants. I. Distribution, physiology and metabolism. New Phytologist, London, v.66, p.143-184, 1967.

LEWIS, D.H. Mannitol acetyl phosphate phosphotransferase of Aspergillus. Transactions of the British Mycological Society, London, v.6, p.391, 1971.

MOWER, R.L. et al. Sugars from Sphacelia sorghi honeydew. Carbohydrate Research, London, v.27, p.119-134, 1973.

MOWER, R.L.; HANCOCK, J.G. Mechanism of honeydew formation by Claviceps species. Canadian Journal of Botany, Canada, v.53, p. 2826-2834, 1975.

POLLARD, C.M.D.; DICKERSON, A.G. Observation on location of $\beta$-glucanase and an associated $\beta$-glucosidase in Claviceps purpurea during its development on rye. Physiological Plant Pathology, St. Paul, v.21, p.179-191, 1984. 